\title{
NOTES TO CONTRIBUTORS
}

GENETICAL RESEARCH publishes original work on all aspects of genetics, or in any field of research which has an important bearing on genetics. Reviews of topical interest will also be considered. Papers will be submitted to referees, and will generally be printed in order of acceptance. Short papers (see below) will be given priority in publication.

CONTRIBUTIONS are welcomed from scientists of all nationalities but must be written in English. Papers should be sent to one of the Executive Editors (see addresses inside front cover), or to a member of the Editorial Board with a particular interest in that area of genetics. Submission of a paper will be taken to imply that it is unpublished and is not being considered for publication elsewhere. Papers should be as concise as clarity permits, and illustrations should be restricted to the minimum needed.

SHORT PAPERS This category is designed for concisely written reports of work for which rapid publication is considered desirable. Such papers will normally be published within three months of receipt in acceptable form. They-should-not-exceed 4 pages of print in length, and should include a summary.

TYPESCRIPTS A top copy and two other copies should be submitted. The top copy should be typed with doublespacing on one side of good quality paper, leaving margins of about $1 \frac{1}{2}$ inches at the left-hand side and at the top and bottom of each sheet. Each copy should include a complete set of illustrations. The title should ordinarily identify the organism. The address of the laboratory at which the work was carried out will be printed with the authors' names at the head of the paper, and changes of address may be added in footnotes. A footnote to the title page should also give the name and address to whom reprint requests may be made. Sources of financial support should be included with other acknowledgements at the end of the text. The title page of the typescript should include a short title for running headlines (limited to 50 letters and spaces), and the name and address of the author (or his proxy) to whom the proofs are to be sent, under the heading: Proofs to be sent to ... Main headings should be typed in capitals and (except summary and references) numbered consecutively. Subheadings should be typed in lower case, and underlined except for those words and symbols which would be italicized in the text. Subheadings should be numbered (i), (ii), etc., within each main heading. Numeral 1 and letter el: if your typewriter uses one symbol for both, please make clear to the Printer which is intended in formulae, gene symbols, etc.

SUMMARY The summary will be printed at the beginning of the paper. It should give a concise abstract of the significant content and conclusions of the paper, in a form suitable for abstracting journals to use, and should not exceed 250 words.

ILLUSTRATIONS The separate category of Plates no longer applies in the new format. All illustrations, including photographs, diagrams, graphs etc. are to be labelled consecutively Figure $1,2 \ldots$ according to their relative positions in the text. Each figure should have a legend to be printed underneath it. Photographs should be supplied as unmounted glossy prints, with a sketch or separate set to show the arrangement required. when several photographs are to form one figure. The names of the authors and the orientation of the figure should be indicated on the back of each photograph. Diagrams should be about twice the size of the printed figure, but not larger than $12 \times 8$ inches, unless exceptionally complicated, and the thickness of lines and size of points should be determined accordingly. They may be submitted as glossy photographic prints or be drawn in indian ink on white Bristol-board, tracing linen or graph paper ruled in pale blue (but not other colours). The lettering on drawings should be lightly inserted in soft pencil only, so that the printer can put in the finished lettering. Legends to illustrations must be given on a separate sheet of paper. Each illustration must have the name of the author and figure number pencilled on the back.

TABLES Each table should be typed on a separate sheet of paper and its approximate position in the text indicated on the typescript. Each should be numbered and carry an appropriate title. The table should be designed, whenever possible, to be printed in the normal orientation of the text. The data should be grouped so as to make the use of rules unnecessary. Vertical rules, in particular, are expensive to print, and will only be included at the Editor's discretion. Table footnotes should ordinarily employ the symbols-*, $\ddagger \S \S, \|, \eta, * *$, etc., in that order.

SумвоLS Gene and mathematical symbols should generally be printed in italics. Please underline those to be italicized when they appear in the text and tables. Bold letters add to printing costs and should only be used where they are necessary to avoid confusion. The author must assume responsibility for the accurate printing of complex mathematical formulae submitted in typewritten form, by differentiating between letters and numbers which are open to misinterpretation, and identifying all Greek, Hebrew and script letters by means of marginal notes at their first appearance. Note that Greek symbols cannot be italicized and that ' + ' as the symbol for a wild-type allele should not be italicized.

NOMENCLATURE Wherever possible, standardized nomenclature should be employed. The author should refer to the following publications for guidance: Novick et al. (Bacteriological Reviews 40, 168-189) for plasmids; O'Brien (Ed.), Genetic Maps 4, Cold Spring Harbor 1987, for recent information on most species and recent gene lists.

REFERENCES should follow the normal usage in the journal. In the list of references at the end of the paper, both titles of articles and names of periodicals should be written out in full.

PROOFS Two sets of single-sided page proofs, together with the typescript of each paper will be sent to the author. The printers' marked proof should be returned after correction to the Executive Editor, together with the typescript Excessive alterations, other than corrections of printers' errors, may be disallowed or charged to the author Corrections should be made using the symbols in British Standard 1219: 1958, or its shortened version B.S. 1219C: 1958.

OFFPRINTS Fifty offprints of each paper, or short paper, are provided free of charge. Additional offprints may be ordered in the form sent out with proofs, provided this is returned within fourteen days of receipt.

\section{Cambridge University Press}

The Pitt Building, Trumpington Street, Cambridge CB2 1RP

40 West 20th Street, New York, NY 10011-4211, USA

10 Stamford Road, Oakleigh, Melbourne 3166, Australia

Printed in Great Britain by the University Press, Cambridge 


\section{Volume 62 No 2 October 1993}

Genetical Res., Camb.

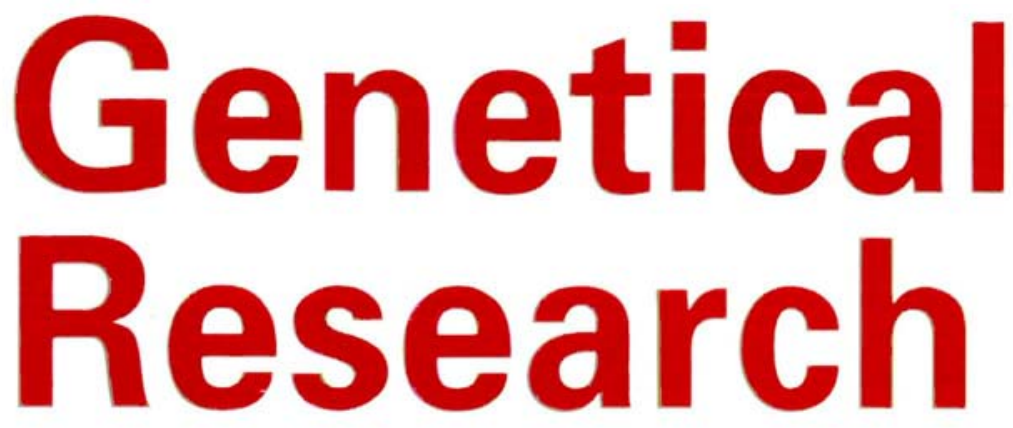

\section{Contents}

NJIOKOU, F.; BeLLeC, C.; BERREBI, P.; DeLAY, B. and JARNe, P. Do selffertilization and genetic drift promote a very low genetic variability in the allotetraploid Bulinus truncatus (Gastropoda: Planorbidae) populations? MIYASHITA, N. T.; AGUADÉ, M. and LANGLEY, C. H. Linkage disequilibrium in the white locus region of Drosophila melanogaster

WANG, Y.; BALTER, H.; LEVITAN, M. and MARGULIES, L. Mutability, sterility and suppression in $P-M$ hybrid dysgenesis: the influence of $P$ subline, cross, chromosome, sex and $P$-element structure

NUZHDIN, S. V; KEIGHTLEY, P. D. and PASYUKOVA, E. G. The use of retrotransposons as markers for mapping genes responsible for fitness difference: between related Drosophila melanogaster strains

SILVER, L. M. and B UCK, C. The mouse t complex distorter-3 (Tcd-3) locus and transmission ratio distortion

TADA, T.; TAKAGI, N. and ADLER, I.-D. Parental imprinting on the mouse $X$ chromosome: effects on the early development of $X 0, X X Y$ and $X X X$ embryos BARTON, N. H. The probability of fixation of a favoured allele in a subdivided population

BOOK REVIEWS

A Short Course in Bacterial Genetics. By Jeffrey H. Miller. DAVID R. F. LEACH Lyme Disease: Molecular and Immunologic Approaches. S. E. Schutzer ed. PATRICIA A. NUTTALL Introduction to Basic Cell Culture: Animal Cell Culture. By S. J. Morgan and D. C. Darling. KIYOSHI MIYAGAWA

Human Gene Mutation. By David N. Cooper and Michael Krawczak. DAVID J. H. BROCK

Cystic.Fibrosis: Current Topics Vol. 1. J. A. Dodge, D. J. H. Brock and $J$. H. Widdicombe eds. ANN HARRIS and ANNE THOMSON Archibald Garrod and the Individuality of Man. By Alexander G. Bearn. DAVID J. H. BROCK

Preimplantation Diagnosis of Genetic Diseases: A New Technique in Assisted Reproduction. $Y$. Verlinsky and A. M. Kuliev eds. DAVID J. H. B ROCK Handbook of Quantitative Forest Genetics. L. Fins, S. T. Friedman and J. V. Brotshol eds. S. J. LEE Mutants at Xantha and Albina Loci in Relation to Chloroplast Biogenesis in Barley. By Knud W. Henningsen, John E. Boynton and Diter von Wettstein. TRISTAN A. DYER BOOKS RECEIVED 